\title{
The choice of animal feeding system influences fatty acid intakes of the average French diet
}

\author{
Bernard Schmitt ${ }^{1}$, Constance Ferry ${ }^{1}$, Guillaume Mairesse ${ }^{2,}$, Nathalie Kerhoas ${ }^{3}$, Guillaume Chesneau ${ }^{2}$, \\ Pierre Weill ${ }^{3}$ and Jacques Mourot ${ }^{4}$ \\ ${ }^{1}$ Centre d'enseignement et de recherche en nutrition humaine, centre hospitalier de Bretagne-Sud, 56322 Lorient, France \\ 2 VALOREX, La Messayais, 35210 Combourtillé, France \\ 3 Association Bleu-Blanc-Cœur, La Messayais, 35210 Combourtillé, France \\ ${ }^{4}$ INRA, UMR 1348 PEGASE, 35590 Saint-Gilles, France
}

Received 23 December 2016 - Accepted 9 April 2017

\begin{abstract}
Fatty acids intake of French adult population does not comply with the French Population Reference Intakes (PRI). The aim the study is to quantify the impact of a modification of animal feeding system on the fatty acids intake of French population. A 15-day diet representative of average consumption for the French adult male population was developed with animal products derived either from conventional production system (STD) either from a specific production system (Bleu-BlancCœur $\left.{ }^{\infty}[\mathrm{BBC}]\right)$ that acts on the fatty acids profile of animal products. The impact of a such change in feeding system on fatty acids content has been quantified. BBC diet contributes to reducing the gap between the fatty acid content of a STD diet and the PRI with highest impact on C12:0-14:0-16:0 fatty acids $(-4.6 \mathrm{~g} / \mathrm{d}$, i.e. $63.3 \%), \mathrm{C} 18: 3 \mathrm{n}-3(+0.8 \mathrm{~g} / \mathrm{d}$, i.e. $48.2 \%), \mathrm{C} 20: 5 \mathrm{n}-3(+35 \mathrm{mg} / \mathrm{d}$, i.e. $42.7 \%)$, $\mathrm{C} 22: 6 \mathrm{n}-3(+49 \mathrm{mg} / \mathrm{d}$, i.e. $35 \%)$ and the $\mathrm{C} 18: 2 \mathrm{n}-6 / \mathrm{C} 18: 3 \mathrm{n}-3$ ratio $(-4.9$ points, i.e. $43.5 \%)$. The research also shows that animal products complement one another. Consuming a variety of animal source foods derived from a specific feeding practices could help reduce the gap between actual consumption and recommended dietary intake of fatty acids.
\end{abstract}

Keywords: fatty acids / animal products / production system / Population Reference Intakes (PRIs) / average French diet

\begin{abstract}
Résumé - Le choix du système alimentaire en élevage influence les apports en acides gras du menu moyen français. Les apports alimentaires en acides gras dans la population française ne répondent pas aux apports nutritionnels conseillés (ANC). Un menu sur 15 jours, représentatif de la consommation moyenne pour la population française des hommes adultes, a été élaboré en utilisant des produits animaux issus soit de modes de production standard (STD) soit d'une filière spécifique (Bleu-BlancCœur ${ }^{\text {[BBC] }}$ qui agit sur le profil en acides gras des produits animaux. L'impact du changement de mode de production sur les apports en acides gras au regard des ANC a été quantifié. Les résultats montrent que le menu $\mathrm{BBC}$ permet de contribuer en moyenne à hauteur de $41 \%$ à la réduction des écarts entre les apports d'un menu STD et les ANC, les plus fortes contributions s'établissant pour les acides gras C12-C14-C16:0 (-4,6g/j, soit 63,3\%), C18:3n-3 (+0.8 g/j, soit 48,2 \%), C20:5n-3 $(+35 \mathrm{mg} / \mathrm{j}$, soit $42,7 \%)$ et le rapport C18:2n-6/C18:3n-3 (-4,9 points, soit $43,5 \%)$. Les travaux ont également démontré la complémentarité des divers produits animaux aux apports en acides gras totaux. La consommation de différents produits animaux de filière spécifique permet donc de réduire efficacement l'écart entre consommation réelle et apports conseillés en acides gras.
\end{abstract}

Mots clés : acides gras poly-insaturés n-3 / mode de production / apports nutritionnels conseillés (ANC) / menu moyen français

\footnotetext{
* Correspondence: g.mairesse@valorex.com
} 


\section{Introduction}

In industrialized societies, eating habits and lifestyle such as increase in energy intake and decrease in energy expenditure are identified as potent promoters of chronic diseases such as cardiovascular diseases or obesity (Cordain et al., 2005). In addition, western diet composition of foods are also pointed out, especially the fatty acids composition (Simopoulos, 2008; Chardigny, 2013). Due to agribusiness and modern agriculture, western diets contain excessive levels of n- 6 polyunsaturated fatty acids (PUFAs) but very low levels of n-3 PUFAs leading to an unhealthy $n-6 / n-3$ ratio of 20:1, instead of $1: 1$ that was during evolution in humans (Simopoulos, 2008).

In general, public health strategies aimed at changing the nutrient intake in the population can take many forms, from focusing purely on human behaviour via food- and meal-based recommendations to invisible pathway such as the modification of the food composition. In France, different national programs took place in order to help modification of the dietary habits of the French population: in 2001, the French National Nutrition and Health Program (Programme national nutrition santé [PNNS]); in 2011, the "Plan obésité » (French national program to combat obesity) and in 2013 the « Plan national de l'alimentation » (French national diet programme [PNA]). The various actions taken through these programs, such as public education on healthier eating, have helped change consumption habits. For example, fruit consumption rose $(+16 \%$ on average for adults) and consumption of sugary foodstuffs fell ( -22 to $-27 \%$ in adults) between 1999 and 2007 (Dubuisson et al., 2010).

As in others countries, the French Population Reference Intakes (PRIs or apports nutritionnels conseillés) for lipids highlights the importance of a better balance between n-6 and n-3 PUFA (ANSES, 2011a). Indeed, food consumption survey INCA 2 demonstrated that the French adult intakes of alpha-linolenic acid (C18:3n-3, ALA) should be multiplied by 2.5 , that of docosahexaenoic acid (C22:6n-3, DHA by 1.8), and that of eicosapentaenoic acid (C20:5n-3, EPA) by 2.5 to reach the PRIs (Dubuisson et al., 2010; ANSES, 2011b). Additionally, the PRIs highlights the importance of differentiating the three saturated fatty acids (C12:0-C14:0-C16:0) from the other types of saturated fatty acids (SFAs) (ANSES, 2011a).

Animal products are the main contributors to the lipid intake of the French population, representing 60 to $67 \%$ depending on the study (Tressou-Cosmao et al., 2015; Tressou et al., 2016). Yet, the lipid content of animal products is highly dependent on the production system used, and on feed in particular. Indeed, there is a direct correlation between the nature of fatty acids ingested by the animal and those present in the derived milk, meat and eggs (Chilliard et al., 2008; Wood et al., 2008; Mourot and de Tonnac, 2015). For example, it has been clearly demonstrated that the n-3 FA content of meat and fat from livestock (beef, pork, chicken, etc.) can substantially be enhanced through altered feeding strategies - especially through replacement of n-6-rich grains, oils and oilseeds (like wheat, maize, soybean, sunflower seeds, etc.) with n-3-rich oils and oilseeds (like fish oil, rapeseed, flaxseed, etc.) and/or grass in the animal's diet (De Henauw et al., 2007; Shapira et al., 2008; Wood et al., 2015).
Alongside these educational measures that aim to change food consumption habits, another pathway to enhance the nutrient intake and more specifically fatty acids intake of a population, is the fortification/enrichment of commonly used foods or ingredients which can take place on the level of processing techniques or of production or feeding systems, such as meat production.

In France in 2000, the Bleu-Blanc-Cour ${ }^{\circledR}$ (BBC) food label established specifications as regards husbandry and feeding practices, reintroducing plants with a high ALA content (grass, alfalfa, flaxseed, etc.) in animal feed. Such changes in feeding practices lead to the marketing of animal products with improved lipid profile in relation to conventional practices, and that comply with nutritional recommendations such as increase in n-3 PUFA, drop in n-6 PUFA/n-3 PUFA ratio, and drop in SFAs (ANSES, 2011b; Mourot and de Tonnac, 2015). Nonetheless, although differences in lipids profile are clear between conventional products and those from the BBC food label, it appears necessary to measure the impact of such a change in production system on the lipid and fatty acids intakes of humans on an average French diet and evaluate the contribution of this system to reach the nutritional adequacy in fatty acids.

\section{Material and methods}

\subsection{Elaboration of the 2-week meal plan (average diet)}

An average 15-day meal plan, that is representative of male French adult $(18$ years +$)$ population diet, was created. To do this, a restricted database was created in order to elaborate the French representative diet with a restricted number of foodstuffs. It was built on the CCAF survey "Comportements et Consommations Alimentaires en France", which takes into account the food choices of this population and match actual consumption patterns (Hébel, 2012). Briefly, the CCAF database was carried out on a sample of 1389 adults representative of the French adult population $(18$ years +$)$. It took note of food consumption over seven days, with an estimate of portions using photographs. Consumption (without waste) was then organised into 38 food groups and 1300 foodstuffs. For each foodstuff, the following information was available: consumption data (in $\mathrm{g} / \mathrm{d}$ ), the percentage in relation to the food group and the penetration rate (percentage of the sample having eaten this foodstuff). To create the restricted database, two steps were followed (Fig. 1):

- selection of food groups: from the 38 CCAF food groups, only the food groups having a penetration rate of over $50 \%$ were retained (called "major food groups", Fig. 1). In order to be exhaustive, consumption of foodstuffs belonging to non-selected groups (called "minor food groups", Fig. 1) was divided among the major groups. The "mixed dishes" CCAF group includes a wide variety of dishes, some of which are composed of a single group of foodstuffs (vegetables, carbohydrates, meats or fish). These increase the overall consumption (in $\mathrm{g} / \mathrm{d}$ ) for their respective group (e.g. ratatouille in the "vegetables" group, veal stew in the "meats" group). Thus, the quantity of mixed dishes is reduced by as much as the other groups concerned are increased. In the present study, the "sauce" CCAF group, is combined with the "fats" group, proportionally to the sauce's fat content. By approaching the portions of the 

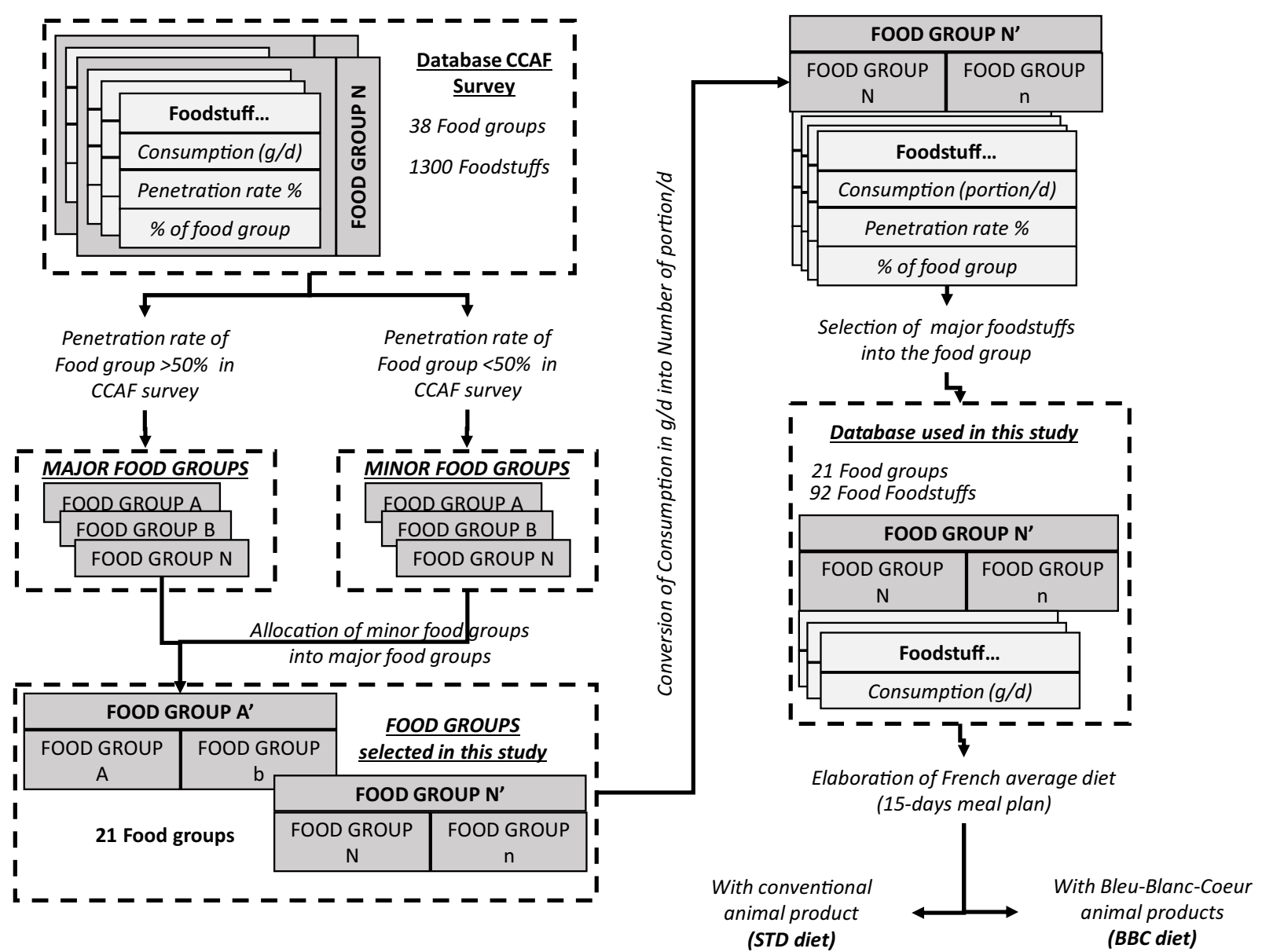

Fig. 1. Methodology used to create the restricted database from the CCAF survey database, in order to model the French diet.

GEM-RCN (2011), this first selection stage leads to a distribution into portions for 15 days in each of 21 food groups (Tab. 1);

- selection of the foodstuffs: among each of the 21 food groups, foodstuffs that strongly resemble another are merged (e.g. cooked ham, cured ham, etc.), as is their consumption in $\mathrm{g} / \mathrm{d}$. Foodstuffs retained in the database are those most often consumed in terms of quantity $(\mathrm{g} / \mathrm{d})$, that have the highest penetration rate, and that represent over $50 \%(\mathrm{~g} / \mathrm{d})$ of the entire group of foodstuffs they belong to. At the end of this step, a list of 92 foodstuffs including 15 elaborate dishes, belonging to 21 food groups was drawn up (Fig. 1).

Based on the restricted database including a list of 92 foodstuffs belonging to 21 food groups and on the number of portions over 15 days for each of these foodstuffs, the construction of a meal plan (breakfast, lunch and dinner) for a 2 -week period was done. This meal plan is known as the "average diet".

Two alternatives of the average diet were tested. The first alternative is based on animal products from conventional feeding system (STD diet) whereas the second one used animal products from BBC feeding system (BBC diet) (Fig. 1).

\subsection{Evaluation of the nutritional intake for STD and BBC diets}

The average consumption quantity ( $\mathrm{g} / \mathrm{d}$ ) of each foodstuff was determined for average diet and remained equal for STD and $\mathrm{BBC}$ diets. In order to take into account the effect of production system, the elaborates dishes in the average diet have been broken down into simple components (flour, butter, pasta, vegetables, fruit, etc.).

These quantitative data estimates were then used to calculate the nutritional average energy value of the diets, its protein, carbohydrate, and lipids content, as well as its fatty acids profile. To do this, the French food composition database CIQUAL (ANSES, 2013) is used for all the nutritional profile (energy, protein, carbohydrates, lipids) of foodstuffs. Contents in monounsaturated fatty acids (MUFAs), PUFAs and SFAs, as well as in C12:0-14:0 16:0 fatty acids, ALA, EPA, DHA and linoleic acid (LA), also comes from CIQUAL database for all foodstuffs, except for meats, meat products, eggs, and dairy products, whose fatty acids profiles were updated. Indeed, CIQUAL data available for animal products do not take into account the impact of the production system on the product's fatty acids profile. Thus, and in order to take into account the difference 
Table 1. Quantity (g) of the different food groups consumed for 15 days.

\begin{tabular}{|c|c|c|c|}
\hline Food groups & Quantity (g/15 d) & Reference portions (g) (GEM-RCN, 2011) & Number of portions $/ 15 \mathrm{~d}$ \\
\hline Poultry & 615 & 120 & 5.1 \\
\hline Fish & 430.6 & 115 & 3.7 \\
\hline Eggs and egg products & 225.3 & 120 & 1.9 \\
\hline Milk & 320.9 & 150 & 2.1 \\
\hline Fat and oil/sauces & 426.8 & 13 & 30.4 \\
\hline Vegetables & 3439.7 & 100 & 34.4 \\
\hline Cooked legumes & 200.2 & 200 & 1 \\
\hline Bread & 2101.6 & 50 & 42 \\
\hline Rice and semolina & 389 & 150 & 2.6 \\
\hline Desserts & 597.5 & 100 & 6 \\
\hline Fruits & 2765.7 & 150 & 18.4 \\
\hline Pastry & 1061.3 & 130 & 8.2 \\
\hline Sugars & 615.5 & 40 & 15.4 \\
\hline
\end{tabular}

in fatty acids profile of foodstuffs according to their production system (conventional versus Bleu-Blanc-Coeur), other data sources are used (Tabs. 2 and 3). This data is drawn directly from the database established from the BBC association monitoring programme, which compiles the analyses of fatty acids profiles on animal products produced using its production system (data from 2010 to 2013) and/or from scientific literature referring to these products. In the $\mathrm{BBC}$ diet, only the fatty acids profile of animal products (meats, meat products, dairy products, milk, butter, eggs) was amended in relation to the STD diet, the quantities of all foodstuffs remaining unchanged.

\section{Results}

The macronutrient composition of the average STD diet is close to the average intake indicated in the CCAF survey (Tab. 4). Deviations observed are all below $4 \%$.

Changes in the feeding system towards $\mathrm{BBC}$ lead to a significant drop in SFAs intake $(-3.2 \mathrm{~g} / \mathrm{d})$ and in particular in C12-C14-C16:0 fatty acids $(-4.6 \mathrm{~g} / \mathrm{d})$, and to an increase in MUFAs $(+2.3 \mathrm{~g} / \mathrm{d})(\mathrm{Tab} .5)$. In the BBC diet, PUFAs increase by $+1.1 \mathrm{~g} / \mathrm{d}$. More specifically, the ALA, EPA and DHA content of the diet increases respectively by $0.8 \mathrm{~g} / \mathrm{d}(+80 \%)$, $35 \mathrm{mg} / \mathrm{d}(+43 \%)$ and $49 \mathrm{mg} / \mathrm{d}(+35 \%)$ in comparison with the STD diet. As regards fatty acids, the BBC diet contributes to reducing the gaps between the content of STD diets and French PRIs, the highest contributions being for C12-C14-C16:0 fatty acids (63.3\%), ALA (48,2\%), EPA (42.7\%) and the LA/ ALA ratio (43.5\%) (Tab. 5). Also of note, the change in production system enables EFSA recommended intake to be met for ALA, EPA and DHA (EFSA, 2010) these recommendations being lower than the French PRIs.

Changes in meat (meat, poultry and meat products) production systems contribute respectively to a $72 \%$ and $48 \%$ increase in ALA and EPA in the average French diet (Tab. 6). Eggs are predominant in the increase of DHA content $(66 \%)$. Dairy products (including cheeses and fats) are an important contributor to the increase in EPA intake (43\%) and represent a solid majority $(87.6 \%)$ in reducing the intake of $\mathrm{C} 12-\mathrm{C} 14$ C16:0 saturated fatty acids.

\section{Discussion}

\subsection{Fatty acids composition of animal products}

One of the main stakes of the present study was to define the fatty acids composition of animal products from STD or BBC feeding system. Indeed, it is difficult to define what is a standard animal feed because it exists various feeding strategies, genetics, or seasonal effects that could deeply modify the fatty acids composition of animal products study (ANSES, 2011b). In the CIQUAL database, no information about animal feed was available for animal products. Thus, in some cases, fatty acids composition of products found in CIQUAL were inconsistent with the fatty acids profiles of products found into scientific literature. The strategy adopted in the present study was thus to determine the relative deviation in fatty acids contents between standard and n-3 PUFA enriched diets according to scientific literature, considering that experimental conditions could be deeply different between studies (genetics, composition of control diets, n-3 PUFA diets contents, etc.), and to determine thereafter the fatty acids profile of STD products. 


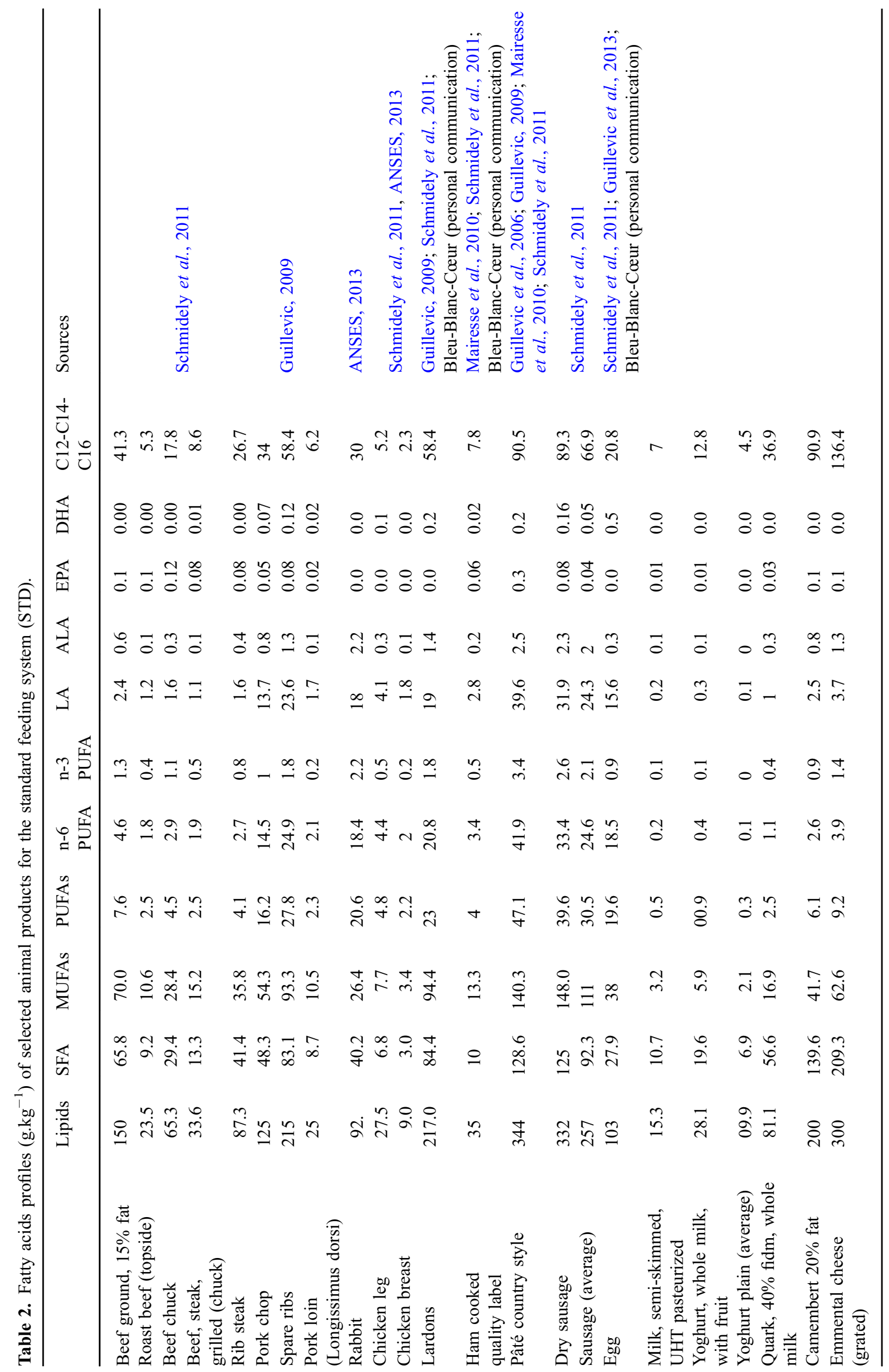




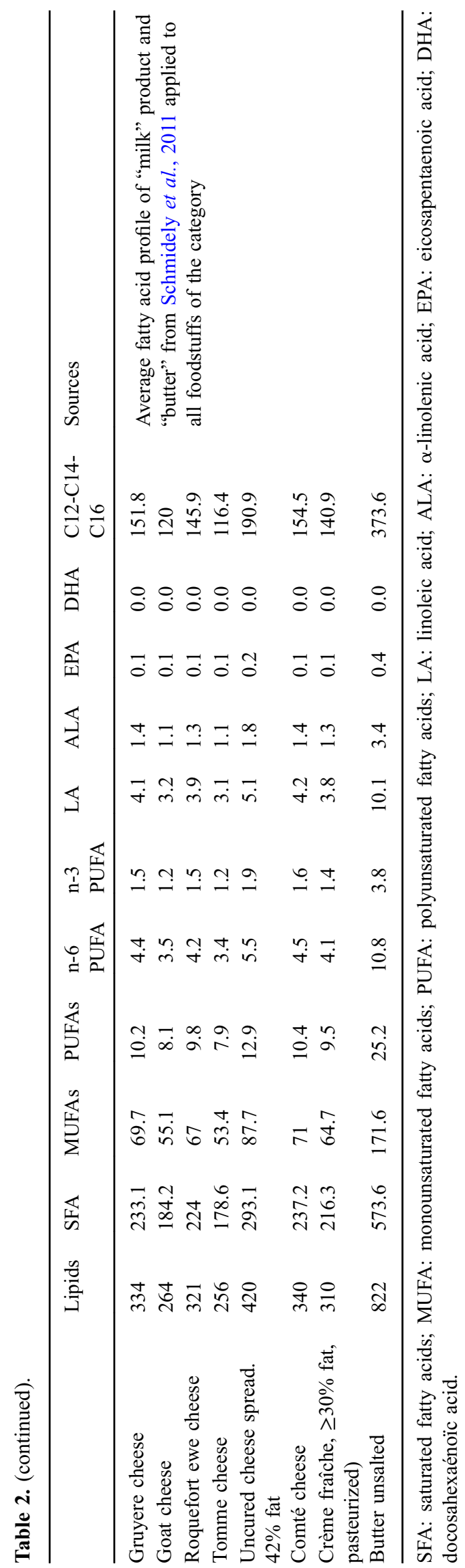

For monogastric products, the main differences between BBC and STD feeding systems were for n-3 PUFA contents, others FA contents remaining quite similar. In the present study, ALA contents for BBC pork products were in average 3.6- and 3.3-fold higher for ALA and n-3 PUFA respectively, with a high variability between pork products. The drop in n-3 PUFA content is two times higher for fat (pork chop and spare ribes, paté, lardons) than lean meats products (loin or ham). According to Guillevic et al. (2009) and Guillevic (2009), ALA contents of different pork products were 5.4 to 6.6 times higher with an extruded linseed supplementation in feed compared to a control diet. However, in this previous work as for others studies, the doses of linseed supplementation into pork diets were about two to three times higher than the BBC specifications. Because of a clear linear effect between n-3 intakes and n-3 deposit in tissues, the value retained in the present study was lower than those reported in scientific literature (Woods and Fearon, 2009; De Smet and Vossen, 2016). According to Mourot and de Tonnac (2015), in the context of a nutritional input that conforms to $\mathrm{BBC}$ specifications, ALA content was multiplied by 2 to 4 compared to a standard feeding system, depending on pork products.

For poultry meats, ALA contents were about four times higher for BBC than STD, as reported in a review on products from BBC production system (Mourot and de Tonnac, 2015). In a review focused on the effect of feeding strategies to modify the fatty acids composition of animal products (ANSES, 2011b), the ratio between ALA content in poultry meat produced with linseed-rich feed versus control feed varied from 1.8 to 5 depending on dosis or form (crushed linseed, linseed oil).

For eggs, the ALA content is 8.7-times higher for BBC than in STD, which is similar to the level reported by Mourot and de Tonnac (2015). For DHA, the increase reached 160\% and is lower than those reported in Mourot and de Tonnac (2015) $(+55 \%)$ but similar to the level found in ANSES (2011b) indicating a maximum DHA contents in eggs of about $2 \%$ of total FA contents.

The FA composition of milk is highly variable depending on season, genetic or feeding strategies (ANSES, 2011b). For milk products, relative deviations between STD and BBC were about $-10 \%$ for SFA and $76 \%$ for ALA in BBC products. In a meta-analysis, Glasser et al. (2008) reported a deviation of $-12 \%$ in SFA and $46 \%$ for ALA of milk between winter bovine diets without lipid supplementation compared to n-3 PUFA rich diets with n-3 PUFA (supplementation with linseed). According to ANSES (2011b), the deviation for ALA was about $75 \%$ and $-12 \%$ for SFA.

For beef meat, SFA were reduced in average by $4 \%$ in BBC products, which is close to the level reported in other study (ANSES, 2011b). ALA contents were doubled for BBC, which is similar to Bauchart et al. (2010) and Normand et al. (2006), but lower than the average drop of $187 \%$ reported by Mourot and de Tonnac (2015) for different genetics and basal diets, mainly because of a higher ALA contents in beef diets.

\subsection{Nutritional evaluation of BBC and STD diets}

The method used in this study to model a 15-day meal plan that is representative of average French consumption, has demonstrated its suitability. Nutritional profile values for the 


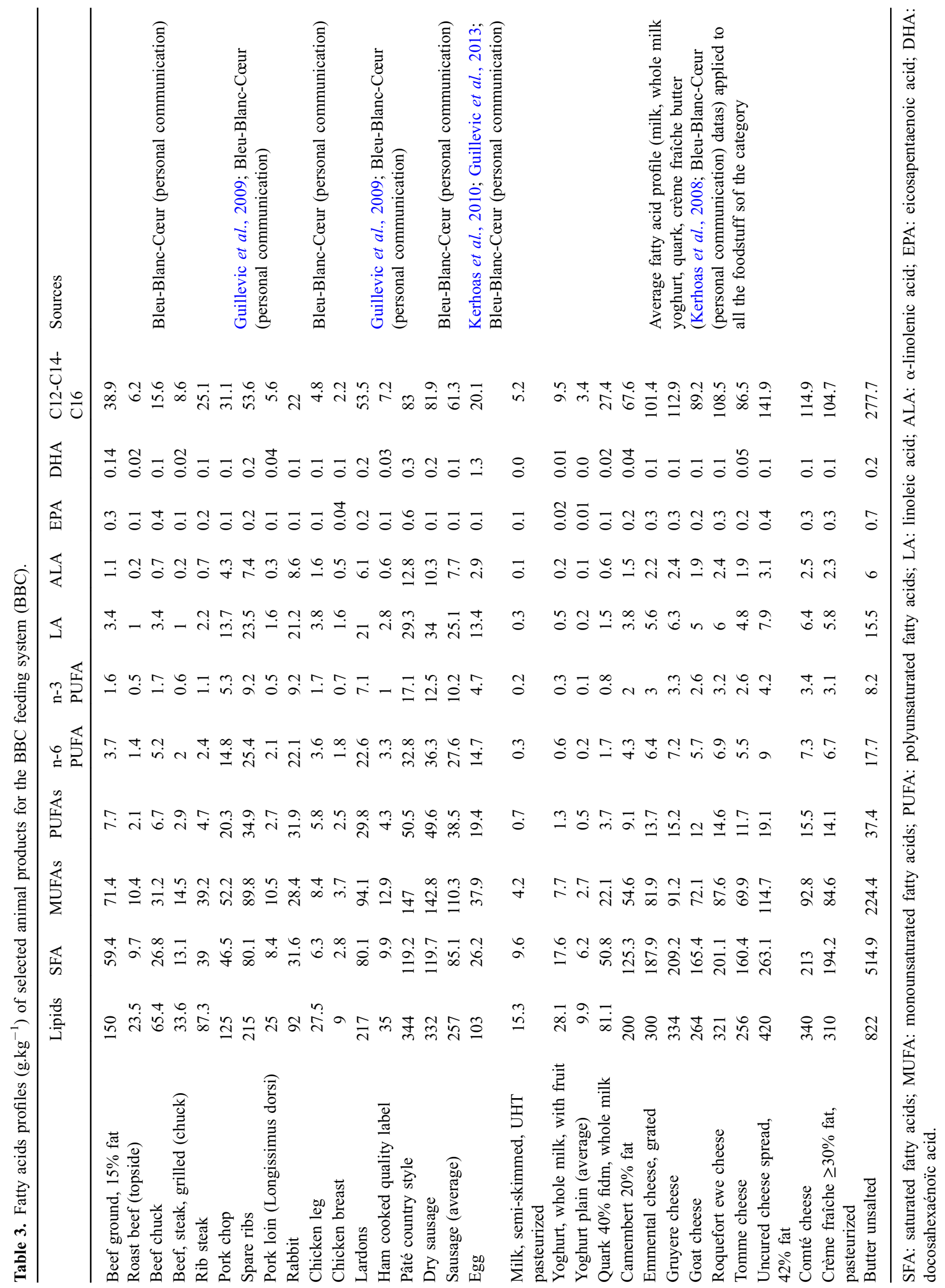


Table 4. Comparison between the average daily intakes of macronutrients from CCAF survey (CCAF 2010) and from the present STD diet.

\begin{tabular}{|c|c|c|c|c|c|c|}
\hline & \multicolumn{3}{|c|}{ CCAF(2010) Survey } & \multicolumn{3}{|c|}{ STD Diet } \\
\hline Energy & & 2275.4 & & & 2295.2 & \\
\hline Protein & 103.2 & 413.0 & 18.1 & 103.8 & 415.0 & 18.1 \\
\hline Carbohydrates & 259.1 & 1036.6 & 45.6 & 256.6 & 1026.5 & 44.7 \\
\hline Lipids & 92.7 & 834.4 & 36.7 & 94.9 & 853.7 & 37.2 \\
\hline PUFA & 12.9 & 116.3 & 5.1 & 13.0 & 117.2 & 5.1 \\
\hline
\end{tabular}

SFA: saturated fatty acids; MUFA: monounsaturated fatty acids; PUFA: polyunsaturated fatty acids; E: total energy intake.

Table 5. Fatty acids daily intake of the standard (STD) and BBC diets.

\begin{tabular}{|c|c|c|c|c|c|c|c|c|}
\hline & \multirow[t]{2}{*}{$\begin{array}{l}\text { French PRI } \\
\text { (ANSES, 2011) }\end{array}$} & \multirow[t]{2}{*}{$\begin{array}{l}\text { EFSA PRI } \\
(\text { EFSA, 2010) }\end{array}$} & \multicolumn{2}{|c|}{ STD diet } & \multicolumn{2}{|c|}{$\mathrm{BBC}$ diet } & \multicolumn{2}{|c|}{$\begin{array}{l}\text { Contribution (\%) of the BBC diet to the reduction } \\
\text { of gap between STD diet and PRI }\end{array}$} \\
\hline & & & $\mathrm{g} / \mathrm{d}$ & $\mathrm{E} \%$ & $\mathrm{~g} / \mathrm{d}$ & $\mathrm{E} \%$ & French PRI & European PRI \\
\hline MUFA & $15-20 \% \mathrm{E}$ & - & 32.9 & 12.89 & 35.2 & 13.79 & $12.7-42.7$ & - \\
\hline PUFA & - & - & 13.0 & 5.11 & 14.2 & 5.55 & - & - \\
\hline n-6 PUFA/n-3 & - & - & 9.1 & & 5.0 & & - & - \\
\hline \multicolumn{9}{|l|}{ PUFA } \\
\hline LA & $4 \% \mathrm{E}$ & $4 \% \mathrm{E}$ & 10.4 & 4.08 & 10.6 & 4.15 & - & \\
\hline ALA & $1 \% \mathrm{E}$ & $0.5 \% \mathrm{E}$ & 0.9 & 0.36 & 1.7 & 0.65 & 45.3 & 207 \\
\hline LA/ALA & $\leq 4$ & - & 11.3 & & 6.4 & & 67.1 & - \\
\hline EPA & $250 \mathrm{mg}$ & \}$=250 \mathrm{mg}$ & 0.083 & 0.03 & 0.118 & 0.05 & 20.1 & \} 300 \\
\hline
\end{tabular}

PRI: Population Reference Intakes; SFA: saturated fatty acids; MUFA: monounsaturated fatty acids; PUFA: polyunsaturated fatty acids; LA: linoleic acid; ALA: $\alpha$-linolenic acid; EPA: eicosapentaenoic acid; DHA: docosahexaenoic acid; E: total energy intake.

Table 6. Contributions of animal products to average BBC diet change in fatty acids intakes compared to STD diet.

\begin{tabular}{|c|c|c|c|c|c|c|c|c|c|c|}
\hline & SFA & MUFA & PUFA & n-6 PUFA & n-3 PUFA & LA & ALA & EPA & DHA & $\mathrm{C} 12-\mathrm{C} 14-\mathrm{C} 16$ \\
\hline \multicolumn{11}{|l|}{ Red meats } \\
\hline $\mathrm{mg} / \mathrm{d}$ & -244.3 & 36.1 & 119.3 & -1.9 & 112.6 & 40.8 & 100.9 & 9.0 & 6.1 & -150.5 \\
\hline$\%$ total gap & 8 & 2 & 11 & -1 & 11 & 24 & 14 & 26 & 13 & 3 \\
\hline \multicolumn{11}{|l|}{ Poultry meats } \\
\hline $\mathrm{mg} / \mathrm{d}$ & -82.6 & 35.3 & 115.9 & 7.5 & 91.3 & 15.1 & 82.7 & 1.7 & 2.6 & -74.0 \\
\hline$\%$ total gap & 2.6 & 1.5 & 10.2 & 3.6 & 9.1 & 8.9 & 11.3 & 4.8 & 5.4 & 1.6 \\
\hline \multicolumn{11}{|l|}{ Meat products } \\
\hline $\mathrm{mg} / \mathrm{d}$ & -365.0 & -15.9 & 389.9 & 57.1 & 465.0 & -25.4 & 344.0 & 6.3 & 1.2 & -321.6 \\
\hline$\%$ total gap & 11.3 & -0.7 & 34.4 & 27.7 & 46.4 & -14.9 & 46.8 & 17.8 & 2.4 & 7.0 \\
\hline \multicolumn{11}{|l|}{ Eggs } \\
\hline $\mathrm{mg} / \mathrm{d}$ & -64.5 & -5.9 & -7.5 & -148.6 & 145.4 & -87.5 & 98.3 & 3.1 & 32.2 & -26.1 \\
\hline$\%$ total gap & 2.0 & -0.3 & -0.7 & -72.2 & 14.5 & -51.3 & 13.4 & 8.8 & 66.1 & 0.6 \\
\hline \multicolumn{11}{|l|}{ Milk products } \\
\hline $\mathrm{mg} / \mathrm{d}$ & -2477.5 & 2233.2 & 515.5 & 291.7 & 186.9 & 227.4 & 109.3 & 15.2 & 6.6 & -4051.6 \\
\hline$\%$ total gap & 76.6 & 97.8 & 45.5 & 141.7 & 18.7 & 133.4 & 14.9 & 43.0 & 13.6 & 87.6 \\
\hline \multicolumn{11}{|l|}{ Total gap } \\
\hline $\mathrm{mg} / \mathrm{d}$ & -3234.0 & 2282.7 & 1133.2 & 205.8 & 1001.2 & 170.4 & 735.2 & 35.3 & 48.7 & -4623.8 \\
\hline
\end{tabular}

Milk products: milk, yoghurts, cheeses, milk fat (butter and crème fraîche). 
average French diet in our study are close to the consumption averages found in the "alcohol-free ration of an adult male population" observed in the CCAF survey (Hébel, 2012) for the male adult population. The diet constructed here therefore realistically replicates the average consumption of the French population and makes it possible to conduct a relevant assessment of the impact of the animal production system on fatty acids intake in a diet.

Tressou et al. (2016) quantified fatty acids intake of the French population from INCA 2 gross consumption data and updated CIQUAL nutritional profile tables, and a similar work was done by ANSES (2015) with very close results. In relation to the STD diet in our research (Tab. 5), SFA and C12:0-14:016:0 contents are lower in Tressou et al. (2016) and ANSES (2015) by about $13 \%$. ALA content is higher by $7 \%$ and the LA/ALA ratio is 9.5 versus 11.3, while DHA levels are equivalent (147.2 mg/d versus $139 \mathrm{mg}$ ). Despite these differences, which may potentially be due to the time difference between the survey (2006 versus 2010), the limited number of selected foodstuffs and the review of foodstuff fatty acids profile conducted for our study, all studies observe that the PRIs are not reached in an average diet, in line with the results presented. While certain strategies to reach the PRIs focus on replacing foodstuffs by others, the approach used in this study acts only on the animal production system and more specifically feeding, without changing the foodstuff itself.

Our results demonstrate that the impact of changes in husbandry feeding practices enable an overall significant improvement in fatty acids content. Dairy products act on the intake of C12-C14-C16:0 fatty acids, even though the drop is different depending on the study, $-4.0 \mathrm{~g} / \mathrm{d}$ in our own study (Tab. 6) against $-2.4 \mathrm{~g} / \mathrm{d}$ in the study led by ANSES (2011b). Additionally, in this same study, the impact of eggs on the intake in ALA is lower than that noted here $(+76 \mathrm{mg} / \mathrm{d}$ versus $+98 \mathrm{mg}$ / d). The same trend can be observed for DHA $(+11 \mathrm{mg} / \mathrm{d}$ versus $+32 \mathrm{mg} / \mathrm{d}$ ). Conversely, the impact was slightly higher on ALAs for meats $(+712 \mathrm{mg} / \mathrm{d}$ versus $527 \mathrm{mg} / \mathrm{d})$ and dairy products $(121 \mathrm{mg} / \mathrm{d}$ versus $109 \mathrm{mg} / \mathrm{d})$ in the ANSES study as compared with the results found here. These discrepancies may be explained in particular by the fact that the initial data used (INCA 1) is relatively old (it predates by 10 years that used in the present study), and by the lack of assessment of mixed dishes. Additionally, the fatty acids profile of $\mathrm{BBC}$ products relies on a great amount of data from the field and provided by the BBC association, which improves the representativeness of their lipid profile in production condition.

Each food group has a variable and complementary impact on the improvement in fatty acids content of the diet. Dairy products predominantly affect the reduction in C12:0-14:016:0 intake, meat the increase of ALA intake, and eggs the increase of DHA. Yet, considering the significance of animal products in the overall lipids intake (approximately $60 \%$ in the adult French population [ANSES, 2011b]), acting on production systems appears as a relevant and efficient way of meeting the French PRIs. In addition, the results show that the BBC diet is sufficient to reach the objectives set by the EFSA (2010). The most impacted are the pork, milk and beef products. These strategies can also complement the use of plant products that offer interesting fatty acid profiles (replacing oils high in n-6 PUFA with oils high in n-3 PUFA (rapeseed or walnut in particular), the reduction in use of margarines and substitution with non-hydrogenated fats, or the introduction of flax flour in the diet (Mourot, 2009; Weill and Mairesse, 2010; Marpalle et al., 2014). The increase in fat fish consumption is also required to reach the PRIs for DHA, which is not met through the single change in production system for land animals.

\section{Conclusion}

The originality of this work lies in the assessment of the impact of feeding practices on the fatty acid intake of the French population on an average diet, and not in the substitution of products. It demonstrates that improving the nutritional content of foodstuffs by changing the feeding system of animals has a significant impact on the daily average nutritional intake of consumers, and thus makes it possible to reduce the gap between recommended and real dietary intakes. More generally, consuming products from the $\mathrm{BBC}$ feeding system reduces from 14 to $60 \%$, depending on the fatty acid considered, the gaps between average intake and the French PRIs. Consumption of products from this specific feeding system is thus an interesting way to meet the nutritional objectives without huge modification in the French eating habits. Consumption recommendations issued by the PNNS, in particular as regards consumption of fat fish, alongside consumption of animal products with improved fatty acid profiles, would be an interesting combination to improve the nutritional status of consumers, and would enable all French lipids PRI to be met.

The present study has been led in France because BBC feeding system concerned all the different animal products and allow to propose to French consumers these products into a meal approach such as proposed here. However, because the imbalance of n-3 PUFA and n-6 PUFA is widely described in industrialised country (De Smet and Vossen, 2016), the development of such agricultural strategies leading to enhanced nutritional adequacy in a large panel of animal products should nevertheless be encouraged.

Conflicts of interest. Guillaume Mairesse and Guillaume Chesneau work in the scientific department of VALOREX. Pierre Weill, Nathalie Kerhoas and Bernard Schmitt are respectively Chair, Director and co-Chair of the Bleu-BlancCœur Association.

Acknowledgements. This research was financed by the Agence nationale de la recherche (National Agency for Research): ANR-12-ALID-0003, AGRALID.

\section{References}

ANSES. 2011a. Actualisation des apports nutritionnels conseillés pour les acides gras - Rapport d'expertise collective. MaisonsAlfort (France) : Agence nationale de sécurité sanitaire alimentation, environnement, travail (ANSES), pp. 1-327.

ANSES. 2011b. Impact des pratiques en alimentation animale sur la composition en acides gras des produits animaux destinés à 1'Homme. Paris (France) : Agence nationale de sécurité sanitaire alimentation, environnement, travail (ANSES), pp. 1-274.

ANSES. 2013. Composition nutritionnelle des aliments - Tables CIQUAL. Disponible sur http://www.afssa.fr/TableCIQUAL/. 
ANSES. 2015. Apports en acides gras de la population vivant en France et comparaison aux apports nutritionnels conseillés définis en 2010. Maisons-Alfort (France) : Agence nationale de sécurité sanitaire alimentation, environnement, travail (ANSES), pp. 1-192.

Bauchart D, Gobert M, Habeanu M, Parafita E, Gruffat D, Durand D. 2010. Influence des acides gras polyinsaturés n-3 et des antioxydants alimentaires sur les acides gras de la viande et la lipoperoxydation chez le bovin en finition. OCL 17(1): 30-36.

Chardigny JM. 2013. Dietary lipids: less fat or best fat? OCL 20(2): 71-74.

Chilliard Y, Bauchart D, Lessire M, Schmidely P, Mourot J. 2008. Qualité des produits: modulation par l'alimentation des animaux de la composition en acides gras du lait et de la viande. Inra Prod Anim 21: 95-106.

Cordain L, Eaton SB, Sebastian A, et al. 2005. Origins and evolution of the Western diet: health implications for the 21 st century. Am J Clin Nutr 81(2): 341-354.

De Henauw S, Van Camp J, Sturtewagen G, et al. 2007. Simulated changes in fatty acid intake in humans through n-3 fatty acid enrichment of foods from animal origin. J Sci Food Agric 87(2): 200-211.

De Smet S, Vossen E. 2016. Meat: the balance between nutrition and health. A review. Meat Sci 120: 145-156.

Dubuisson C, Lioret S, Touvier M, et al. 2010. Trends in food and nutritional intakes of French adults from 1999 to 2007: results from the INCA surveys. Br J Nutr 103(7): 1035-1048.

EFSA. 2010. Scientific opinion on dietary reference values for fats, including saturated fatty acids, polyunsaturated fatty acids, monounsaturated fatty acids, trans fatty acids, and cholesterol. EFSA J 8(3):1461-1482.

GEM-RCN (Groupe d'étude des marchés de restauration collective et nutrition). 2011. Paris (France) : ministères des Finances et des Comptes publics, pp. 1-105.

Glasser F, Ferlay A, Chilliard Y. 2008. Oilseed lipid supplements and fatty acid composition of cow milk: a meta-analysis. J Dairy Sci 91(12): 4687-4703.

Guillevic M. 2009. Effets des acides gras n-3 sur la construction de la qualité nutritionnelle de la viande de porc et sur le métabolisme des lipides. Thèse de l'Institut supérieur des sciences agronomiques, agro-alimentaires, horticoles et du paysage, Rennes (France), pp. 1-214.

Guillevic M, Blochet J-E., Le Minous A-E., Mourot J. 2006. Qualité nutritionnelle des lipides du pâté de campagne. Viandes Prod Carn: 97-98, hors-série, $11^{\text {es }}$ Journées des sciences du muscle et technologies des viandes.

Guillevic M, Kouba M, Mourot J. 2009. Effect of a linseed diet on lipid composition, lipid peroxidation and consumer evaluation of French fresh and cooked pork meats. Meat Sci 81(4): 612-618.

Guillevic M, Chesneau G, Bopris E, Kerhoas N. 2013. Tous les systèmes d'élevages garantissent-ils une qualité nutritionnelle régulière ? Cah Nutr Diet 48: 57.

Hébel P, 2012. Comportements et consommations alimentaires en France : enquête CCAF 2007-CREDOC 2012. Paris (France) : Tec\&Doc, pp. 1-144.
Kerhoas N, Chesneau G, Bazin F, et al. 2008. Analyse descriptive et comparative de la composition en acides gras des produits laitiers Bleu-Blanc-Cœur. Renc Rech Rumin 15: 116.

Kerhoas N, Guillevic M, Bopris E, Chesneau G, Weill P. 2010. Le mode de production influence la composition lipidique de l'œuf. Nutr Clin Metab 24: S98.

Mairesse G, Benet M, Méteau K, Juin H, Durand D, Mourot J. 2010. L'ajout d'antioxydants végétaux dans l'alimentation des porcs permet-il de limiter la péroxydation des viandes enrichies en acides gras poly-insaturés n-3 ? J Rech Porc 42: 197-204.

Marpalle P, Sonawane SK, Arya SS. 2014. Effect of flaxseed flour addition on physicochemical and sensory properties of functional bread. LWT - Food Sci Tech 58 (2): 614-619.

Mourot J. 2009. Optimising the nutritional and sensorial profile of pork. In: Kerry P, Ledward D, eds. Improving the sensory and nutritional quality of fresh meat. Cork, Ireland: Woodhead Food Science, Technology and Nutrition, pp. 342-355.

Mourot J, de Tonnac A. 2015. The Bleu Blanc Cœur path: impacts on animal products and human health. OCL 22(6): D610.

Normand J, Quinsac A, Doreau M. 2006. Incidence d'un apport alimentaire d'acides gras polyinsaturés en cours d'engraissement sur les performances zootechniques et les qualités des viandes de gros bovins - Compte rendu final $n^{\circ} 170632$ 029. Institut de l'élevage, département techniques d'élevage et qualité - service qualité des viandes, Paris, France.

Schmidely P, Brunschwig P, Enjalbert F, Etienne M, Lessire M, Sauvant D, et al. 2011. Impact des pratiques en alimentation animale sur la composition en acides gras des produits animaux destinés à l'Homme. Paris (France) : ANSES, pp. 1-274.

Shapira N, Weill P, Loewenbach R. 2008. Egg fortification with n-3 polyunsaturated fatty acids (PUFA): nutritional benefits versus high n-6 PUFA Western diets, and consumer acceptance. Isr Med Assoc J 10: 262-265.

Simopoulos MD. 2008. The importance of the omega- 6 omega- 3 fatty acid ratio in cardiovascular disease and other chronic diseases. Soc Exp Biol Med 233(6): 674-688.

Tressou-Cosmao J, Pasteau P, Le Guillou C, Simon N. 2015. Analyse des apports nutritionnels en acides gras de la population française à partir des données INCA 2. Paris (France) : ONIDOL, pp . 1-70.

Tressou J, Pasteau S, Dartinet SD, Simon N, Le Guillou C. 2016. Données récentes sur les apports en acides gras des Français. $O C L$ 23(3), D303.

Weill P, Mairesse G. 2010. Le lin, son huile, sa graine... et notre santé. Phytothérapie 8(2): 84-88.

Wood JD, Enser M, Fisher AV, Nute GR, Sheard PR, Richardson RI, et al. 2008. Fat deposition, fatty acid composition and meat quality: a review. Meat Sci 78: 343-358.

Wood KE, Mantzioris E, Gibson RA, Ramsden CE, Muhlhausler BS. 2015. The effect of modifying dietary LA and ALA intakes on omega-3 long chain polyunsaturated fatty acid (n-3 LCPUFA) status in human adults: a systematic review and commentary. Prost Leukot Essent Fatty Acid 95: 47-55.

Woods VB, Fearon AM, 2009. Dietary sources of unsaturated fatty acids for animals and their transfer into meat, milk and eggs: A review. Livest Sci 126(1-3): 1-20.

Cite this article as: Schmitt B, Ferry C, Mairesse G, Kerhoas N, Chesneau G, Weill P, Mourot J. 2018. The choice of animal feeding system influences fatty acid intakes of the average French diet. OCL 25(2): D205. 